\title{
GOOD ENVIRONMENTAL GOVERNANCE IN INDONESIA (PERSPECTIVE OF ENVIRONMENTAL PROTECTION AND MANAGEMENT)
}

\author{
Purniawati \\ Faculty of Law, Universitas Negeri Semarang, Indonesia \\ Nikmatul Kasana \\ Faculty of Law, Universitas Negeri Semarang, Indonesia \\ Rodiyah \\ Department of Administrative and Constitutional Law \\ Faculty of Law, Universitas Negeri Semarang, Indonesia \\ Email: purniawati@gmail.com
}

\begin{abstract}
This paper discusses good environmental governance in the framework of environmental protection and management. The evironmental view of governance itself provides a conceptual framework in which public and private behavior is regulated in supporting more ecologically oriented arrangements. The framework forms a reciprocal relationship between the community (global, regional, national and local) in dealing with the access and use of environmental goods and services and binds them (at any level) with certain specific environmental ethics. Then as a system, Environmental Governance consists of socio-cultural aspects, political and economic interactions among many actors in civil society. In managing and protecting the environment around it is needed cooperation between humans, humans are very important to manage and protect the environment in which they live. Starting from the government and until the people have the same rights and obligations in managing and protecting the environment without exception. Not limited wherever domicile. Both rural communities, rural and urban areas, become an important part of the realization of a good and healthy environment. The existence of the community will be very effective if its role in controlling the management of the exis ting environment.
\end{abstract}

Keywords: Good Environmental Governance; Environmental Law; Policy; Environmental Protection

The Indonesian Journal of International Clinical Legal Education DOI: 10.15294/ijicle.v2il.37328

https://journal.unnes.ac.id/sju/index.php/iccle

C 2020 Authors. This work is licensed under a Creative Commons AttributionShareAlike 4.0 International License. All writings published in this journal are personal views of the authors and do not represent the views of this journal and the author's affiliated institutions.

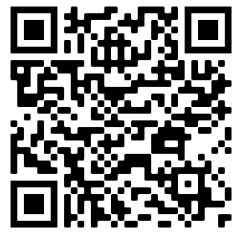




\section{PENDAHULUAN}

Usaha pelestarian lingkungan hidup yang selama ini didominasi oleh kerangka pikir manajemen telah membuat usaha ini tidak mencapai hasil yang diinginkan. Keterbatasan kerangka manajemen telah membuat usaha tersebut terjebak pada ketergantungannya terhadap pemerintah. Kerangka pikir manajemen melihat lingkungan hidup hanya sebagai obyek manajemen.

Lingkungan juga dapat diartikan menjadi segala sesuatu yang ada di sekitar manusia dan mempengaruhi perkembangan kehidupan manusia. Sedangkan dalam Undang Undang No. 23 Tahun 1997 telah dijelaskan, lingkungan hidup adalah kesatuan ruang dengan semua benda, daya, keadaan, dan makhluk hidup, termasuk manusia dan perilakunya, yang mempengaruhi kelangsungan perikehidupan dan kesejahteraan manusia serta makhluk hidup lain. Sedangkan ruang lingkup lingkungan hidup Indonesia meliputi ruang, tempat Negara Kesatuan Republik Indonesia yang berwawasan Nusantara dalam melaksanakan kedaulatan, hak berdaulat, dan yurisdiksinya.

Dalam perlindungan dan pengelolaan lingkungan hidup tidak terlepas dari peran pemerintah untuk membuat kebijakan terkait dengan terciptanya lingkungan yang baik dan sehat.Pada era saat ini, permasalahan kerusakan lingkungan tengah menjadi perhatian banyak pihak. Karena potensi kerusakan lingkungan terus muncul seiring dengan majunya pembangunan di segala bidang. Tidak dapat dipungkiri bahwa di era modernisasi saat ini banyak sekali aspek pembangunan yang tidak preventif terhadap lingkungan atau dengan kata lain tidak memperdulikan aspek kelestarian lingkungan sekitar. Maka untuk mereduksi potensi kerusakan lingkungan yang sangat besar tersebut, dan untuk mengimplementasikan salah satu prinsip good governance terkait komitmen pada perlindungan lingkungan hidup tersebut, maka lahirlah sebuah konsep baru dalam manajemen pengelolaan lingkungan hidup yakni enviromental governance. Environmental governance merupakan paradigma baru di bidang lingkungan hidup dimana menjadi bagian penting dari pencapaian good governance. Selain itu konsep enviromental governance diharapkan dapat menjadikan aspek lingkungan sebagai mainstream utama pembangunan di indonesia yang sama-sama menjalankan aspek ekonomi dan sosial.

Evironmental governance menyediakan sebuah kerangka kerja konseptual dimana tingkah laku publik dan swasta diatur dalam mendukung pengaturan yang lebih berorientasi pada ekologis. Kerangka kerja tersebut membentuk hubungan yang timbal balik antara masyarakat (global, regional, nasional dan lokal) dalam berhubungan dengan akses dan penggunaan barang dan jasa lingkungan serta mengikat mereka (dalam tingkatan apapun) dengan etika-etika lingkungan spesifik tertentu.Kemudian sebagai sistem, Environmental Governance terdiri atas aspek sosial budaya, interaksi politik dan ekonomi diantara banyak 
aktor dalam masyarakat madani. Dalam mengelola dan melindungi lingkungan hidup di sekitar diperlukan kerjasama antara manusia, manusia sangat berperan penting untuk mengelola dan melindungi lingkungan hidup tempat dimana ia tinggali. Mulai dari pemerintah dan sampai masyarakat mempunyai hak dan kewajiban yang sama dalam mengelola dan melindungi lingkungan tanpa terkecuali. Tidak terbatas dimanapun domisilinya. Baik masyarakat desa, pelosok maupun kota, menjadi bagian penting dari perwujudan lingkungan hidup yang baik dan sehat. Keberadaan masyarakat akan efektif sekali jika perannya dalam mengontrol pengelolaan lingkungan yang ada. ${ }^{1}$ Beberapa aplikasi dari peran serta masyarakat dalam pengelolaan lingkungan hidup tercemin dari kebijakan pemerintah. Kebijakan dimaksud diaplikasikan dalam bentuk konkret yang langsung ditujukan kepada masyarakat mengaplikasikannya dalam tindakan konkret dalam bentuk aktivitas. Ini adalah dimensi dari peran serta masyarakat yang merupakan cerminan dari kebijakan pemerintah untuk terciptanya lingkungan hidup yang baik dan sehat. $^{2}$

\section{KONSEP GOOD ENVIRONMENTAL GOVERNANCE}

Usaha pelestarian lingkungan hidup yang selama ini didominasi oleh kerangka pikir manajemen telah membuat usaha ini tidak mencapai hasil yang diinginkan. Keterbatasan kerangka manajemen telah membuat usaha tersebut terjebak pada ketergantungannya terhadap pemerintah. Kerangka pikir manajemen melihat lingkungan hidup hanya sebagai obyek manajemen.

Konsep governance dalam lingkungan atau bisa disebut dengan environmental governance, melihat negara dan masyarakat sebagai obyek sekaligus subyek pada usaha pelestarian lingkungan. Negara sebagai suatu organisasi yang memiliki kontrol terhadap sumberdaya dan kekuasaan, memiliki kemampuan mengubah kondisi alam dalam skala yang masif. Oleh karena itu, nasib lingkungan hidup sangat ditentukan oleh kemampuan menertibkan perilaku negara agar konsisten dengan kaidah-kaidah ekologis. Melalui konsep governance ini maka environmental governance dipahami sebagai kerangka pikir pengelolaan negara dalam rangka pengelolaan lingkungan hidup melalui interaksinya dengan rakyatnya. Tapi perlu diingat bahwa peran negara disini adalah untuk memastikan arah dan derajat perubahan sesuai dengan yang bisa ditolerir oleh ekosistem, bukan kemampuan negara mengubah kondisi bio-fisik.

1 Wahidin Samsul, 2014, Dimensi Hukum Perlindungan dan Pengelolaan Lingkungan Hidup, Yogyakarta: Pustaka Belajar, hlm 174

2 Ibid. 
Konsep environmental governance perlu dibangun diatas sebuah premis sentral bahwa sistem sosial dan ekosistem dari waktu ke waktu terlibat dalam interaksi (aksi-reaksi) yang tidak berkesudahan. Interaksi antar kelompok yang berkembang dalam konsep governance telah membuat hubungan antara negara, masyarakat, dan swasta berdiri sejajar. Governance pada konsep environmental governance digunakan pada keperluan untuk memahami dan mengelola hubungan timbal balik antara sistem sosial dengan ekosistem.

Adapun konsep penegakan hukum lingkungan dalam UUPPLH terdiri dari penegakan hukum administrasi, perdata dan pidana. Yang perinciannya adalah sebagai berikut:

1. Konsep penegakan hukum administrasi

a. Pelaksanaan pemerintahan yang diberikan oleh Gubernur/Bupati/ Walikota

b. Penerapan pengenaan uang paksa

c. Pencabutan izin usaha (penutupan perusahaan) oleh pejabat pemberi izin

d. Penerapan audit lingkunganwajib oleh Menteri Negara Lingkungan Hidup

2. Konsep penyelesaian sengketa lingkungan yang berupa

a. Penyelesaian sengketa di luar Pengadilan dengan cara negoisasi

b. Mediasi, fasilitasi, musyawarah dan abitrase

c. Penyelesaian sengketa di Pengadilan melalui gugatan perdata

3. Konsep penegakan hukum pidana yang berupa
a. Tindak pidana materil
b. Tindak pidana formil
c. Tindak pidana korporasi
d. Tindakan tata tertib
e. Tindak pidana lingkungan hidup adalah kejahatan. ${ }^{3}$

Menrurut Soerjono Soekanto agar konsep penegakan hukum dalam good environmental governance akan berjalan dengan baik dan sempurna, apabila empat faktor ini dipenuhi.

\section{PRINSIP GOOD ENVIRONMENTAL GOVERNANCE DALAM PENGELOLAAN LINGKUNGAN HIDUP}

Sebagaimana telah dijelaskan sebelumnya bahwa good environmental governance dimaknai sebagai pengelolaan pemerintahan yang baik (good governance) yang peduli terhadap kelangsungan dan kelestarian lingkunganhidup. Pentingnya pemerintahan yang baik, oleh karena

3 Machmud Syahrul, 2012, Penegakan Hukum Lingkungan Indonesia, Yogyakarta: Graha Ilmu, hlm.105 
penyelenggaraan pemerintahan yang baik akan menentukan sejauh mana tujuanpenyelenggaraan pemerintahan itu bisa tercapai.

Pemerintahan yang sudah mampu mewujudkan Good Governance belum tentu memiliki kepedulian terhadap aspek keberlanjutan ekosistem. Seperti yang diusung oleh environmetalism. Oleh sebab itu pemerintah yang telah mengupayakan aktualisasi prinsip-prinsip Good Governance masih memerlukan persyaratan tambahan yaitu mengaitkan seluruh kebijakan pembangunan dengan prinsip-prinsip keberlanjutan ekologi (ecological sustainability). ${ }^{4}$ agar dapat dikatakan sebagai good environmental governance

Menurut Siahaan. ${ }^{5}$ azas-azasp enyelenggaraa nnegara yang baik dalam mengelola lingkungan dengan prinsip keberlanjutan sumber daya (sustainability) disebut dengan prinsip Good Environmental Governance (GEG). Sedangkan menurut world bank dalan Belbase. ${ }^{6}$

"...it necessary to achieve the sustainable use of resources and the protection of environmental quality. This objective requires a atransparent system of well-functioning environmental institutions, policies, and programs that actively involve the public in their formulation and implementation."

Hal tersebut menjelaskan bahwa Good Environmental Governance merupakan sebuah kegiatan penting untuk mensukseskan penggunaan sumber daya alam secara bekelanjutan dan melindungi kualitas lingkungan. Kegiatan ini membutuhkan transparansi sistem pada institusi lingkungan, kebijakan dan program-program yang melibatkan masyarakat dalam merumuskan dan penerapan kebijakan-kebijakan. Selain itu, budiati. ${ }^{7}$ berpendapat Environmental Governance sebagai framework pengelolaan negara melalui interaksinya dengan rakyat, dalam rangka pengelolaan lingkungan hidup.

Sonny Kerap menegaskan bahwa ada hubungan erat antarapenyelenggaraan pemerintahan yang baik dengan pengelolaan lingkungan hidup yang baik. Penyelenggaraan pemerintahan yang baik akan mempengaruhi dan menentukan pengelolaan lingkungan hidup yang baik, dan pengelolaan lingkungan hidup yang baik mencerminkan tingkat penyelenggaraan pemerintahan yang baik. Tegasnya, tanpa penyelenggaraan pemerintahan yang baik, sulit mengharapkan akan adanya pengelolaan lingkungan hidup yang baik.

4 Pandji Santosa, 2008, Administrasi Publik: Teori dan Aplikasi Good Governance, Bandung: PT.Refrika Adifama, hlm.131

5 Siahaan.N.H.T, 2004, Hukum Lingkungan dan Ekologi Pembangunan, Jakarta: Erlangga, hlm.32

6 Narayan Belbase, 2010, Environmental Good Governance In The Future Constitution In Nepal, hlm.4-13, IUCN Nepal

7 Lilin Budiati, 2012, Good Governance Dalam Pengelolaan Lingkungan Hidup, Bogor: Ghalia Indonesia, hlm.65 
Hyronimus Rhiti berpendapat bahwa good governance yang berkaitan dengan aspek pengelolaan lingkungan itu, juga berkaitan dengan pelaksanaan asas-asas umum pemerintahan yang baik. Menurut Hyronimus, dari 13 (tiga belas) asas umum pemerintahan yang baik, yang berkaitan dengan urusan lingkungan hidup antara lain asas kepastian hukum, keseimbangan, tidak mencampuradukkan kewenangan, keadilan dan kewajaran, menanggapi harapan yang ditimbulkan, dan asas penyelenggaraan kepentingan umum.

16 Keterkaitan antara penyelenggaraan pemerintahan yang baik (good governance) dengan masalah pengelolaan lingkungan hidup juga dikemukakan Mas Achmad Santosa yang mengambil contoh berbagai kerusakan lingkungan yang terjadi pada masa pemerintahan Orde Baru, yang menurut Achmad Santosa disebabkan pemerintahan tidak memiliki goodgovernance. Akan tetapi, ketiadaan kemauan politik (political will) pemerintah bukan merupakan satu-satunya faktorkendala dalam mewujudkan good governance, utamanya dalam urusan pengelolaan lingkungan. Lemahnya penerapan good governance selama ini, terutama pada masa pemerintahan Orde Baru, menurut Achmad Santosa selain tidak ada kehendak politik yang kuat dari pemerintah, kelemahan aktivis lingkungan dalam birokrasi, ornop maupun universitas yang mengkaitkan antara good governance sebagai prasyarat dasar pengelolaan lingkungan hidup yang efektif dengan isu lingkungan yang diadvokasi juga merupakan kendala dalam mewujudkangood governance.

Penyelenggaraan pemerintahan yang baik, mensyaratkan beberapa hal, yaitu: pertama, penyelenggaraan pemerintahan yang baik mensyaratkan agar pemerintah itu sendiri benar-benar efektif dalam memerintah. Sebab, selamapemerintah lemah dan tidak efektif, kekuasaan pemerintah bisa menjadibulan-bulanan dan menjadi alat permainan kepentingan kelompok tertentu dengan mengorbankan kepentingan rakyat banyak. Kedua, untuk menjamin penyelenggaraan pemerintahan yang baik, pemerintah harus patuh terhadap aturan hukum yang berlaku. Hal ini berarti bahwa setiap penyelenggara pemerintahan harus menjadi contoh yang baik dalam mematuhi hukum. Tanpa kepatuhan terhadap hukum, tidak akan ada kepastian hukum, dan selama tidak ada kepastian hukum tidak mungkin bisa dijamin ada penyelenggaraan pemerintahan yang baik.Ketiga: Prinsip Transparansi. Transparansi dibangun atas dasar arus informasi yang bebas. Seluruh proses pemerintahan, lembaga-lembaga dan informasi perlu dapat diakses oleh pihak-pihak yang berkepentingan, daninformasi yang tersedia harus memadai agar dapat dimengerti dan dipantau. Penerapan prinsip keterbukaan (transparency) merupakan suatu keharusansebagai bentuk open governance yang memudahkan bagi swasta dan masyarakat untuk mengakses berbagai informasi mengenai perencanaan dan pelaksanaan pembangunan. Kemudahan dalam melakukan akses informasi memungkinkan swasta dan masyarakat dapat lebih maksimal 
dalam menggunakan hak untuk berperan serta dalam perencanaan dan pelaksanaan pembangunan.

Peran serta masyarakat dalam penyelenggaraan pemerintahan memiliki dasar hukum yang kuat. Undang-undang Nomor 32 Tahun 2004tentang Pemerintahan Daerah (UU Pemda 2004).Undang-undang Nomor 32 Tahun 2009 tentang Perlindungan dan Pengelolaan Lingkungan Hidup (UU PPLH) juga mengatur mengenai peran serta masyarakat dalam pengelolaan lingkungan hidup. Peran serta masyarakat juga diatur berkaitan dengan penyusunan analisis mengenai dampak lingkungan (Amdal). Pasal 26 UU PPLH mengatur bahwa dokumen Amdal disusun oleh pemrakarsa dengan melibatkan masyarakat. Pelibatan masyarakat harus dilakukan berdasarkan prinsip pemberian informasi yang transparan dan lengkap serta diberitahukan sebelum kegiatan dilakukan.Peran serta masyarakat dalam pengelolaan lingkungan hidupmempunyai jangkauan luas. ${ }^{8}$ Peran serta tersebut tidak hanya meliputi peran serta individu yang terkena berbagai peraturan perundang undangan atau keputusan administratif, akan tetapi meliputi pula peran serta kelompok dan organisasi dalam masyarakat. Adapun pokok fikiran yang melandasiperlunya peran serta masyarakat dalam pengelolaan lingkungan hidup adalah: 1) memberi informasi kepada Pemerintah; 2) meningkatkan kesediaan masyarakat untuk menerima keputusan; 3) membantu perlindungan hukum; dan 4) mendemokratisasikan pengambilan keputusan. Keempat: Prinsip Peduli pada Stakeholder. Menurut prinsip ini lembaga-lembaga dan seluruh proses pemerintahan harus berusaha melayanisemua pihak yang berkepentingan;

Kelima: Prinsip Berorientasi pada konsensus. Bahwasanya tata pemerintahan yang baik menjembatani kepentingan-kepentingan yang berbeda demi terbangunnya suatu consensus menyeluruh dalam hal apa yang terbaik nagi kelompok-kelompok masyarakat, dan bila mungkin, consensus dalam hal kebijakan-kebijakan dan prosedur-prosedur. Keenam: Prinsip kesetaraan: semua warga masyarakat mempunyai kesempatan memperbaiki atau mempertahankan kesejahteraan mereka; Ketujuh: Prinsip Efektif dan efisien. Proses-proses pemerintahan dan lembaga-lembaga membuahkan hasil sesuai kebutuhan warga masyarakat dan dengan menggunakan sumber-sumber daya yang ada seoptimal mungkin. Kedelapan: Prinsip Akuntabilitas. Para pengambil keputusan di pemerintahan, sektor swasta dan organisasi-organisasi masyarakat bertanggung jawab baik kepada masyarakat maupun kepada lembagalembaga yang berkepentingan. Bentuk pertanggungjawaban tersebut berbeda satu dengan lainnya tergantung dari jenis organisasi yang bersangkutan.

Kesembilan: Prinsip Visi strategis, dimana para pemimpin dan masyarakat memiliki perspektif yang luas dan jauh ke depan atas tata

8 Nopiyandri, 2014, Penerapan Prinsip Environmental Governance Dalam Rangka Perlindungan dan Pengelolaan Lingkungan Hidup, hlm. 81 
pemerintahan yang baik dan pembangunan manusia, serta kepekaan akan apa saja yang dibutuhkan untuk mewujudkan perkembangan tersebut. Selain itu mereka juga harus memiliki pemahaman atas kompleksitas kesejarahan, budaya dan sosial yang menjadi dasar bagi perspektif tersebut.

Selain prinsip-sprinsip good governance sebagaimana dirumuskan Masyarakat Transparansi Indonesia (MTI) tersebut, kalangan pemerintahdaerah juga melahirkan sepuluh prinsip menuju pemerintahan yang baik, Sepuluh prinsip tata pemerintahan yang baik berdasarkan kesepakatan Asosiasi Pemerintahan Kabupaten Seluruh Indonesia (APKASI), Asosiasi Pemerintahan Kota Seluruh Indonesia (APEKSI) dan Asosiasi DPRD Kota Seluruh Indonesia (ADEKSI) adalah (1) Partisipasi, yaitu mendorong setiap warga untuk menggunakan hak dalam menyampaikan pendapat dalam proses pengambilan keputusan, yang menyangkut kepentingan masyarakat, baik secara langsung maupun tidak langsung; (2) Penegakan Hukum, yaitumewujudkan adanya penegakan hukum yang adil bagi semua pihak tanpa pengecualian, menjunjung tinggi hak asasi manusia dan memperhatikan nilainilai yang hidup dalam masyarakat; (3) Transparansi, yaitu menciptakan kepercayaan timbal balik antara pemerintah dan masyarakat melalui pelayanan penyediaan informasi dan menjamin kemudahan dalam memperoleh informasi yang akurat dan memadai; (4) Kesetaraan, yaitu member peluang yang sama bagi setiap anggota masyarakat untuk meningkatkan kesejahteraan; (5) Daya Tangkap, yaitu meningkatkan kepekaan bagi penyelenggara pemerintahan terhadap aspirasi masyarakat tanpa kecuali; (6) Wawasan Ke depan, yaitu membangun daerah berdasarkan visi dan strategi yang jelas dan mengikutsertakan warga dalam seluruh proses pembangunan, hingga warga merasa memiliki dan ikut bertanggungjawab terhadap kemajuan daerahnya; (7) Akuntabilitas, yaitu meningkatkan akuntabilitas para pengambil keputusan dalam segala bidang yang menyangkut kepentingan masyarakat luas; (8) Pengawasan, yaitumeningkatkan upaya pengawasan terhadap penyelenggaraan pemerintahan dan pembangunan dengan mengusahakan keterlibatan swasta dan masyarakat luas; (9) Efisiensi dan efektivitas, yaitu menjamin terselenggaranya pelayanan kepada masyarakat dengan menggunakan sumber daya yang tersedia secara optimal dan bertanggung jawab; dan (10) Profesionalitas, yaitu meningkatkan kemampuan dan moral penyelenggara pemerintahan agar mampu memberikan pelayanan yang mudah, cepat, tepat, dan biaya terjangkau.

Praktik pemerintahan masa lalu, yang mengabaikan prinsipprinsip good governance telah mendatangkan berbagai kerusakan lingkungan, seperti penggundulan hutan, bencana banjir, maraknya illegal logging, dan lain-lain. Praktik pemerintahan di masa lalu, di satu sisi menutup pintu bagi adanya kontrol terhadap jalannya pemerintahan, dan pada sisi lain tidak transparan dalam perencanaan dan pelaksanaan kebijakan pemerintah. Penyelenggaraan pemerintahan berdasarkan 
prinsip good environmental governance memberikan makna bahwa pengelolaan urusan pemerintahan di bidang sumberdaya alam dan lingkungan diselenggaraan sedemikian rupa dengan dilandasi visi perlindungan dan pelestarian fungsi lingkungan hidup dalam mendukung pelaksanaan pembangunan berkelanjutan. ${ }^{9}$

Penyelenggaraan pemerintahan yang baik dan menjunjung prinsip-prinsip good governance akan membawa implikasi terjadinya pengelolaan sumber daya alam dan lingkungan hidup yang baik pula. Sebaliknya, penyelenggaraan pemerintahan yang buruk (bad governance) pada akhirnya akan membawa pengaruh bagi pengelolaanlingkungan hidup yang tidak baik. Dengan kata lain, pengelolaan lingkungan hidup yang baik sangat ditentukan dan dipengaruhi oleh tata pemerintahan yang baik di bidang lingkungan hidup (good environmental governance).

\section{IMPLEMENTASI GOOD ENVIRONMENTAL GOVERNANCE DALAM WILAYAH PESISIR}

Sebagai negara kepulauan, tentunya Indonesia memiliki banyak wilayah pesisir sebagai bagian dari kedaulatan negaranya. Dalam hal ini, wilayah pesisir mempunyai potensi yang signifikan dalam kerangka pengelolaan sumberdaya nasional. Konsep wawasan nusantara menganggap seluruh wilayah baik darat, laut serta udara sebagai suatu kesatuan yang utuh, termasuk di dalamnya wilayah pesisir yang diantaranya menjadi wilayah perbatasan dengan negara lain. Tentunya hal ini menyangkut sistem pertahanan dan keamanan wilayah, terutama dalam hal pengelolaan sumberdaya, baik sumberdaya alam, sumberdaya manusia maupun sumberdaya buatan. Sistem juga sangat diperluka dalam dalam mencegah kepunahan kepunahan keanekaragaman hayati, SDA hayati akan terus menerus menurun hingga mengalami kepunahan, sehingga menghilangkan nilai potensinya. Sistem hukum yang memadai, termasuk pelaksanaan dan penegakannya secara efektif di lapangan, untuk menyelamatkan dan menjamin kelestarian sumber daya alam yang ada di pesisir dalam jangka panjang bagi generasi masa kini dan masa depan. ${ }^{10}$

Ketidakteraturan pengelolaan sumberdaya pesisir dan lautan yang kini berlangsung dan telah terbukti berkontribusi atas sejumlah kerusakan lingkungan, pada intinya disebabkan oleh ketiadaan detail tata ruang yang dapat dijadikan sebagai rujukan pengembangan oleh semua pihak yang berkepentingan. Akibatnya, terjadilah konflik penggunaan

9 Kurniawan Teguh, 2001, Mewujudkan Kepemerintahan Lingkungan (Environmental Governance) di Indonesia, hlm.4

10 Samedi, 2015, Konservasi Keanekaragaman Hayati di Indonesia Rekomendasi Perbaikan Undang-Undang Konservasi,Vol.2, hal.3 
yang sangat kontraproduktif terhadap tujuan pembangunan berkelanjutan.

Penataan ruang secara detail sesuai dengan peruntukannya, juga sangat diperlukan dalam pengembangan budi daya laut sebagai alternatif atas usaha perikanan tangkap yang selama ini dianggap bersifat ekstraktif dan eksploitatif. Ketiadaan tata ruang secara detail dalam pengembangan teknologi budidaya laut, khususnya udang, yang saat ini sangat membantu dalam perolehan devisa negara telah berdampak negatif berupa, di antaranya, terjadinya konversi besar-besaran kawasan mangrove menjadi kawasan budidaya. Akibatnya, keuntungan yang didapatkan dari usaha tersebut tak sebanding dengan kerugian berupa hilangnya segenap fungsi ekosistem yang sangat bernilai. Terjadinya abrasi laut, erosi pantai, perubahan iklim lokal dan hilangnya sejumlah biota potensial yang saat ini terjadi di banyak kawasan di Indonesia sebagai buah dari tidak tertata dan terencananya pengelolaan kawasan pesisir merupakan kerugian yang mestinya tidak perlu terjadi. Karena itu, agar kerugian serupa tidak terulang, penataan ruang secara detail sesuai dengan peruntukannya berdasarkan atas pertimbangan aspek sosial, ekonomi dan ekologi mutlak diperlukan. Untuk itu, beberapa hal di bawah ini perlu dilakukan oleh semua stakeholder pesisir dan lautan khususnya pemerintah:

1. Rehabilitasi kawasan-kawasan pesisir dan lautan yang telah mengalami kerusakan, baik karena pencemaran, sedimentasi, overeksploitasi sumberdaya, maupun perusakan habitat secara fisik.

2. Kedua, Internalisasi biaya eksternalitas ke dalam setiap kegiatan pembangunan. Sebagaimana dimaklumi, bahwa beberapa kegiatan pembangunan mengeluarkan "eksternalitas" (externality). Artinya, kegiatan pembangunan selain menghasilkan manfaat sesuai dengan yang diharapkan juga menimbulkan dampak negatif yang harus ditanggung oleh pihak lain yang umumnya tidak turut menikmati manfaat pembangunan dimaksud. Kasus kematian udang di Pantura Jawa, ikan sapu-sapu akibat pencemaran limbah industri di Lampung beberapa waktu lalu, merupakan biaya eksternalitas yang harus ditanggung oleh para petani tambak/ikan. ikan sapu-sapu akibat pencemaran limbah industri di Lampung beberapa waktu lalu, merupakan biaya eksternalitas yang harus ditanggung oleh para petani tambak/ikan. Padahal, para petani ikan umumnya tidak mendapatkan manfaat apapun dari industri yang menghasilkan limbah tersebut. Adanya kasus biaya eksternalitas ini telah menimbulkan permasalahan penting di wilayah pesisir dan lautan yang perlu mendapatkan perhatian.

Selama ini, sebagaimana telah diuraikan sebelumnya, laut telah menjadi tempat pembuangan limbah oleh sejumlah industri. Adanya limbah ini telah berdampak negatif yaitu turunnya kualitas lingkungan laut yang berimplikasi terhadap penurunan jumlah hasil tangkapan ikan dan berkurangnya turis yang berminat menikmati kebeningan dan kesejukan alam. Kondisi ini bila tidak dilakukan upaya 
pembenahan, akan semakin memperburuk kualitas lingkungan laut karena tidak adanya beban yang harus ditanggung oleh penghasil limbah.

Untuk itu, maka perhitungan setiap nilai kerusakan oleh kegiatan pembangunan perlu dilakukan kemudian diinternalisasikan sebagai komponen biaya produksi bagi pihak-pihak yang menimbulkan eksternalitas. Dengan demikian, akan timbul rasa tanggung jawab pelaksana pembangunan atas setiap kerusakan lingkungan yang dihasilkan. Dalam pada itu, agar proses internalisasi ini dapat terlaksana dengan baik perlu kiranya dibuat suatu sistem perundangundangan yang dapat mendukung konsep tersebut.

3. Penerapan Retribusi atas Setiap Pemanfaatan Sumberdaya Pesisir dan lautan.

Laut sebagai sumberdaya milik bersama sering diartikan sebagai barang gratis (free goods) yang setiap orang boleh mengeksplotasi sekehendak hatinya. Konsekuensinya, laut menjadi tempat penampungan sampah dan sumberdaya yang paling layak untuk eksploitasi. Pengertian yang demikian tentu salah karena berpotensi terjadinya eksplotasi yang tak terkendali. Apabila eksploitasi ini melewati ambang batas pembaharuan dirinya, maka akan terjadi penipisan stok, seperti misalnya dilakukan pada perikanan tangkap. Demikian juga, bila limbah yang dibuang ke laut melebihi daya purifikasinya, kemampuan laut untuk menyerap limbah akan berkurang, dan terjadilah pencemaran laut.

4. Laut sebagai Milik Rakyat yang Harus dikelola secara CoManagement.

Bumi, air dan segala yang terkandung didalamnya merupakan kekayaan milik negara yang harus dikelola untuk kemakmuran rakyat sebagai mana tercantum dalam pasal 33 UUD 1945, adalah salah satu pasal yang paling kontroversial dan sering dituduh sebagai alat penguasaan negara atas sumberdaya alam. Bukan karena penguasannya yang sering dipersoalkan tapi pengelolaan kekayaan tersebut yang dirasakan sangat tidak adil. Tidak berlebihan, apabila pasal tersebut yang paling banyak digugat di era reformasi ini. Kerena kalimat untuk kemakmuran rakyat yang tercantum pada pasal tersebut pada kenyataannya hanya merupakan suatu retorika belaka yang dalam implementasinya tidak ada.

Pengklaiman bahwa laut merupakan kekayaan milik negara sebenarnya kurang sejalan dengan hukum kepemilikan, dimana sumberdaya alam pada umumnya merupakan kekayaan milik bersama. Artinya, rakyat yang mempunyai akses langsung terhadap kekayaan tersebut memiliki hak atas pengelolaan, pemanfaatan dan pemeliharaannya. Lebih tegas lagi, rakyat yang ada di daerah, dalam hal ini adalah masyarakat lokal yang paling berhak atas manfaat sumberdaya alam tersebut.

Selama ini pengelolaan sumberdaya alam yang terdapat di wilayah pesisir dan lautan dari mulai perencanaan, sampai pada tahap 
evaluasi dilakukan oleh pemerintah pusat (top down), tanpa melibatkan masyarakat lokal sedikitpun. Sehingga masyarakat lokal yang notabene mempunyai hak atas sumberdaya alam tersebut tidak bisa menikmatinya atau bahkan mendapatkan akibat dari pengelolaan yang tidak berkelanjutan. Oleh karena itu, saat ini dan di masa mendatang pemerintah harus memberikan sebagian kewenangannya dan mempercayakan kepada masyarakat setempat dalam pengelolaan sumberdaya alam tersebut. Pemerintah harus menyertakan masyarakat sebagai mitra, sekaligus juga mendengarkan keinginan dan nuraninya dalam setiap pengambilan kebijakan pengelolaan sumberdaya alam termaksud. Inilah merupakan pendekatan kebijakan yang memadukan antara keinginan pemerintah pusat (top down) dan suara dari bawah atau masyarakat (bottom up).

5. Reorientasi laut sebagai milik negara ke milik rakyat juga harus direalisasikan dalam bentuk desentralisasi kewenangan pengelolaan (sesuai dengan UU No. 22/1999). Dalam aspek politik international dan pertahanan keamanan, wewenang pemerintah pusat sesuai dengan yurisdiksinya harus tetap dipertahankan. Artinya, pengertian desentralisasi hanya sebatas pengelolaan sumberdaya alam yang terkandung didalamnya agar dapat lebih bermanfaat bagi kebanyakan masyarakat.

6. Wilayah pesisir dan lautan harus dianggap sebagai bagian dari ekosistem global. Selama ini, ada suatu pemikiran yang keliru dalam pemanfaatan sumberdaya pesisir dan lautan, yaitu anggapan pesisir dan lautan sebagai komponen yang terpisah dan bebas dari komponen lain dalam suatu ekosistem global. Karena anggapan pesisir dan lautan sebagai komponen yang berdiri sendiri akan memposisikannya sebagai sumberdaya ekonomi yang dapat dieksploitasi untuk menghasilkan uang secara semena-mena. Untuk menjamin sumberdaya pesisir dan lautan sebagai sumberdaya yang memberikan manfaat berkesinambungan, anggapan yang salah tersebut harus segera diluruskan, dengan menyadari bahwa sumberdaya pesisir dan lautan merupakan salah satu komponen yang tak terpisahkan dari ekosistem dunia (global).

Perubahan tata aturan (governance) dalam pengelolaan sumberdaya pesisir dan lautan merupakan suatu keharusan. Untuk sampai kepada suatu good governance dalam pemanfaatan sumberdaya pesisir dan lautan harus ada perubahan yang mendasar dalam beberapa hal, yaitu:

1. Kriteria Keberhasilan Pembangunan.

Agar pelaksanaan pembangunan pesisir dan lautan untuk mewujudkan pembangunan nasional secara berkelanjutan dapat berjalan, diperlukan reorientasi kebijakan pembangunan yang lebih mengindahkan pertimbangan lingkungan. Salah satu yang mendesak adalah perlunya memodifikasi kriteria daya dukung lingkungan bagi keberhasilan pembangunan dari suatu unit wilayah administrasi 
(propinsi, kabupaten/kota, kecamatan dan desa) atau sektor pembangunan.

2. Perubahan peraturan dan perundang-undangan yang lebih memihak kepada kepentingan rakyat kebanyakan daripada hanya melindungi kepentingan segelintir orang/pengusaha.

3. Perlu UU pemerintahan daerah yang memberikan kewenangan lebih besar kepada daerah dalam hal pengelolaan sumberdaya pesisir dan lautan, dan memberikan perimbangan keuangan yang adil.

Direvisinya UU otonomi daerah memberikan pelajaran bahwa masing-masing daerah harus segera membuat suatu rencana tata ruang untuk menghindari terjadinya konflik kepentingan, sesuai dengan kewenangan yang dimiliki; peraturan tentang pemanfaatan sumberdaya hayati secara optimal dan lestari; dan peraturan mengenai pengendalian pencemaran serta pengendalian perusakan fisik habitat pesisir dan lautan.

4. Pemerintah harus memiliki keberanian politik melakukan dan membuat berbagai kebijakan secara transparan, adil, efisien dan bertanggung jawab.

Komponen bangsa lainnya, yaitu masyarakat, swasta dan pihak-pihak yang berkepentingan juga harus berperan aktif dan terlibat dalam segenap proses kebijakan yang dilindungi oleh UU. Hukum sebagai institusi tertinggi harus benar-benar ditegakan dan semua pihak harus tunduk dan berada di bawah hukum tersebut.

\section{KESIMPULAN}

Dari uraian diatas dapat disimpulkan bawa Good governance merupakan konsep awal dari berlanjutnya good environmental governance sebagai salah satu cara terhdap perlindungan dan pengelolaan lingkugan hidup. Bahwa prinsip good environmental governance dalam pengelolaan dan perlindungan lingkungan hidup berorientasi pada penyelenggaraan pemerintah yang baik Implementasi terhadap prinsip good environmental governance terhadap pengelolaan sumberdaya alam yang terdapat di wilayah pesisir mulai dari perencanan sampai pengelolaannya harus dijalankan oleh pemerintah dan masyarakat. Dengan adanya kerja sama antara pemerintah dan masyarakat dalam menerapkan good environmental governance dalam mengelola dan melindungi lingkungan hidup maka akan tercipta lingkungan hidup yang baik dan sempurna.

\section{REFERENSI}

Machmud, Syahrul, 2012, Penegakan Hukum Lingkungan, Yogyakarta, Graha Ilmu.

Wahidin, Syamsul, 2014, Dimensi Hukum Perlindungan dan Pengelolaan Lingkungan Hidup, Yogyakarta, Pustaka Belajar. 
Santosa, Pandji, 2008, Administrasi Publik: Teori dan Aplikasi Good Governance, Bandung, PT.Refika Aditama.

Siahaan, 2004, Hukum Lingkungan dan Ekologi Pembangunan, Jakarta, Erlangga.

Budiati, Lilin, 2012, Good Governance Dalam Pengelolan Lingkungan Hidup, Bogor, Ghalia Indonesia.

Narayan Belbase, 2010, Environmental Good Governance In The Future Constitution In Nepal, hlm.4-13, IUCN Nepal

Nopiyandri, 2014, Penerapan Prinsip Environmental Governance Dalam Rangka Perlindungan dan Pengelolaan Lingkungan Hidup, hlm. 81

Kurniawan Teguh, 2001, Mewujudkan Kepemerintahan Lingkungan (Environmental Governance) di Indonesia, hlm.4

Samedi, 2015, Konservasi Keanekaragaman Hayati di Indonesia Rekomendasi Perbaikan Undang-Undang Konservasi,Vol.2, hal.3 